\title{
Daddy's slight miscalculation
}

\section{Science at the cutting edge.}

\section{Ashley Pellegrino \\ Zzzzzzt! Clink! "Ouch! \\ I listened from outside Dad's lab. He was working on a new experiment. \\ No one knew Daddy had started a new project, except me. Only I know when he is working on an experiment, because he usually works while my brother and sister and I are asleep. Whenever he is up all night, I know he's working on something new, sometimes even something strange - like the pink octopus whose ears were like wings. \\ He doesn't go out to work in the morn-} ing like other fathers. Did he ever go out to work, like other kids' dads? I think so; but he does not like to talk about the time before I was born. Something happened. Something sad, I think.

Except for us, Dad has only his work.

If you watch science fiction, or read it, you might think it's boring or even scary growing up with a scientist in the house. Actually, it's more interesting than scary, more easy than boring. When I ask for help with my homework, he sometimes gets me all dizzy. Other times, it becomes crystal clear. But don't ask him why nature is the way it is, unless you really want to know, unless you want to get dizzy trying to understand how black paint looks black because it is really trapping all the other colours inside.

"Why is the sky blue?" I remember asking.

Most adults would answer: ${ }^{\alpha} \mathrm{Go}$ ask your science teacher." Or: "That's how God made it."

But Dad said: "That's the colour the sky rejects."

I don't completely understand; but I'm sure not many kids walk around wondering about living in rejected colours. It makes me wonder a lot about the things around me. It's actually kind of fun. Even with ideas gone completely strange, we're always entertained. None of us will ever forget what Dad did to Mr Kitty.

Cat's toes and monkey fingers?

Mr Kitty was already nicknamed Mr Mischief, even without Dad's help.

'Biomorphing' paws into hands - for a cat? Who wouldn't have guessed that could lead to chaos? Just imagine living with a cat that can unscrew jars and open doors. But even if our house did eventually end up with a child lock on the refrigerator door (although there were no toddlers around), it was really fun, believe it or not, to have a cat with hands.

Yet the noises that came from Dad's lab, that night - they sounded more creepy than fun. Usually the sounds coming from Dad's lab are buzzes, not ouches.

So, I knocked.

"Comein," he said.

The sun was shining through his windows and
"But Dad. What happens when...?"

"Don't worry," he said. "Nothing can go wrong. Nothing goes wrong in science, if you really do your homework. Science only improves life."

"Isn't that what they said about the Titanic and the Columbia?" I asked.

“Ouch!" Dad said. "Gotta think about that one. But this science is different. Trust me."

Dad was changing. A lot of people were changing, these days. Some were changing for the better. Some, for the worse.

Dad always used to tell me that the most important place for a scientist to be is in the unknown. " "I don't know," he had taught me, "is always a good place to start." Now, he was starting to speak as if he did know - as if, these days, he was afraid to say the words ${ }^{\alpha} I$ don't know".

I thought again about those angry trees in The Wizard of $\mathrm{Oz}$, and I did not like the whole idea. "Dad, wait..."

But Dad wore the wire anyway, and he flipped the switch, saying: "This is something new. This is something completely different."

Just then, my brother Kyle went into the yard, wanting only to do something nice for Dad. He wanted to give Dad a surprise, and to do some it was a bright new day outside. Dad had worked all night. This had to be something special. I saw what might have been a small device used to communicate with those pink octopuses with Dumbo's ears.

"Dad, what is that?" I asked.

"Bone-phone," Dad replied. There was a strange-looking wire dipped to his ear.

"I don't like the sound of that," I said.

"That's OK. We can always name it again."

"Fine! But, what does it do?"

'Do you see those orchids on the table? And those trees outside? This wire sends a signal right into my brain. It lets me feel exactly what the plants feel. Isn't that amazing?"

I looked at the fruit trees, and I looked at the tall green grass. I thought of The Wizard of Oz. I thought of how the trees yelled at Dorothy when she picked their apples. of the household chores for him. Kyle was heading for the grass. He was pushing Dad's little mechanical lawnmower. He was pushing fast, really fast.

Dad never knew that a single blade of grass could scream. No one knew, until that day. Kyle mowed 20 feet, before Dad's screams stopped him.

Yes, this was as different as Dad promised it would be.

The grass on our lawn is taller than me, now. And the neighbours have begun to complain. But Dad will not cut the grass; not a single blade.

Dad still won't tell me what it sounded like.

And I wonder.

Ashley Pellegrino is the 11-year-old daughter of a scientist. Aside from writing tales that occasionally scare the scientist whose real-life adventures have been known to scare Stephen King, she's a perfectly typical sixth-grader. 